\title{
The Role of ICT-Based Metacognition and Process of Complex Problem Solving Against the Capability of Student Statistics in the Industrial Age 4.0
}

\author{
Rusmini $^{1 *} \quad$ Fitrah Sari Wahyuni $^{1} \quad$ Fachrur Rozi Guntoro ${ }^{2}$ \\ 1. Lecture Potensi Utama Medan University, Jl.KL.Yos Sudaraso Km. 6,5 No.3-A Tanjung Mulia -Medan \\ 2.Hotel Santika Deandra Medan
}

\begin{abstract}
The ability of statistics is the knowledge base of statistical reasoning and statistical thinking. Statistical capabilities in this study it: 1) reasoning for data, 2) Reasoning for basic statistical concepts and terms used in statistics, 3) Reasoning for data collection and processing in descriptive statistics, 4) Basic abilities in translate data, and 5) basic abilities in communicating data and research results. The ability of Statistics can be improved by increasing the role of student metacognition. In the industrial age 4.0, one way to optimize student metacognition skills is to get used to solving complex problems with ICT-based and complex problem-solving processes. The method used is a qualitative method. In Intervention applying learning statistics by developing statistics modules. This research with random samples. .One control and one experimental class. Based on the results of trials I and II that the ability of metacognition has a significant effect on the ability of student statistics where $F_{\text {count }}>F_{\text {table, }}$ which means the role of metacognition is very significant on the ability of student statistics. Students also show a good or positive response.
\end{abstract}

Keywords: Metacognition, ICT and Process Of Complex Problem-Solving, Capability of Student Statistics, Industrial Age 4.0

DOI: $10.7176 / \mathrm{JEP} / 11-18-05$

Publication date:June 30th 2020

\section{Introduction}

The industrial revolution is facing today is the industrial revolution 4.0 in which the economic activities carried out by robots and tools - software that automatically or technology developed in the era of revolution industrial 4.0, such as 1) Computing Power, 2) the speed of communication, 3) Storage Capacity data, 4) sensors, 5) 3D printers, 6) Artificial intelligence, 7) Nero-biotechnology. and 8) Nano-Technology, which is a problem for us are we ready to face such rapid progress? As educators of the strategies and methods that must be prepared for our young generation in undergoing industry 4.0. Skills (abilities) needed in dealing with industry 4.0 some of which are 1) Information media and technology skills, 2) Life and Career Skills, 3) Learning and Innovative Skills, and 4) Effective Communication Skills (Nugraha, 2018). Human resources that can be prepared include learning and Innovation Skills based on information media and technology skills to face the industrial era 4.0. The components included in learning and Innovation Skills with information-based media and technology skills are: components of learning and innovation skills are: 1) Complex Problem solving (complex problems), 2) Curiosity (curiosity) 3) Creativity (creative), 4) Risk-Taking, while the components of information media and technical skills are: 1) media literacy, 2) visual literacy, 3) multicultural literacy, 4) Global Awareness, and 5) Technology Literacy. Efforts that can be done are to improve one's ability to think and one's ability to use awareness to regulate the thought process or increase the role of metacognition.

Increasing the role of metacognition including by getting used to solving complex problems (complex problem solving) with ICT -based and getting used systematically in the process of solving complex problems so that the ability of student statistics increases. Statistical ability is the basis of knowledge from statistical reasoning and statistical thinking. While statistical citizenship is used by researchers to analyze quantitative data to produce decisions that are by following per under existing information. The basis of statistical ability ( statistical competence) as stated above: 1) reasoning for data, 2) Reasoning for basic statistical concepts and terms used in statistics, 3) Reasoning for data collection and processing in descriptive statistics, 4) Basic skills in translating data, and 5) Basic abilities in communicating data and research results (Riadi, 2016). Optimal statistical ability will contribute to the habit of self to work systematically and scientifically. So that this attitude is a capital for students to face the Industrial 4.0 era, where needed reliable human resources with complex and skilled problems using appropriate technological advancements.

But in reality, Indonesian human resources are still below the standard in terms of learning and innovation skills and information media and technical skills. This is evident from the results of the World's Most Literate Nations (WLMN, 2019) that Indonesia ranked Final Rank to 60 with the following criteria: for computers 60 , Education System Input 54, 36.5 Library, Newspaper 55, Education- 45. Furthermore, based on test scores interviews and observations of researchers with students in Potensi Utama University that they have difficulty 
solving complex problems in material statistics, from 38 students given the problem of analyzing the relationship of the cost of advertising with sales volume, only 3 students who answered correctly the rest did not understand, it was indicated that the power Student metacognition is still low. The effort that can be done is to increase the metacognitive role that refers to the three essential skills, namely: planning skills, monitoring skills and evaluation skills, to increase the role of students 'metacognition, that is, getting used to solving complex problem solving based on ICT so that students' statistical abilities become better. Statistical ability is an ability about the theory and method of quantitative data analysis obtained from observations to compare the source of the variance of a phenomenon, to accept or reject hypothetical relationships and make reliable conclusions (Lestari, 2015, Riadi, 2016)

Based on the things mentioned above, it is very necessary to increase the role of ICT -based metacognition and Process of Complex Problem Solving to improve the ability of statistics in the industrial era 4.0. Furthermore, according to Nugraha (2018) the skills needed in dealing with industry 4.0: 1) Information media and technology skills, 2) Life and Career Skills, 3) Learning and Innovative Skills, 4) Effective Communication Skills. As an educator, we can prepare human resources from learning and innovating skills with information-based media and technology skills to face the industrial era 4.0. One of the supporting materials for successful learning and innovation skills is to improve student statistics skills.

Ability statistical ( statistical competence ) in this study include: 1) The reasoning of the data, 2) reasoning to the basic concepts of statistics and terms used in statistics, 3) Reasoning for gathering and processing data on descriptive statistics, 4) Basic skills in translating data, and 5) basic capabilities in communicating fish data and research results. Optimal statistical ability will contribute to work habits systematically and scientifically. To prepare reliable and skilled human resources using appropriate technological advancements.

\section{Research Method}

The method used is a qualitative method according to Davison et.al, 2004 (Lestari, 2015) as a cycle, which at the Intervention (Action Taking) stage the researcher applies learning statistics whereby developing the module statistics linear regression material 4 variables with ICT-based and complex problem-solving processes with questions that will stimulate the increasing role of student metacognition and the complex problems presented are problems that exist around the environment of students in the Industrial age 4.0. The research design concept is presented in Figure 1 as follows

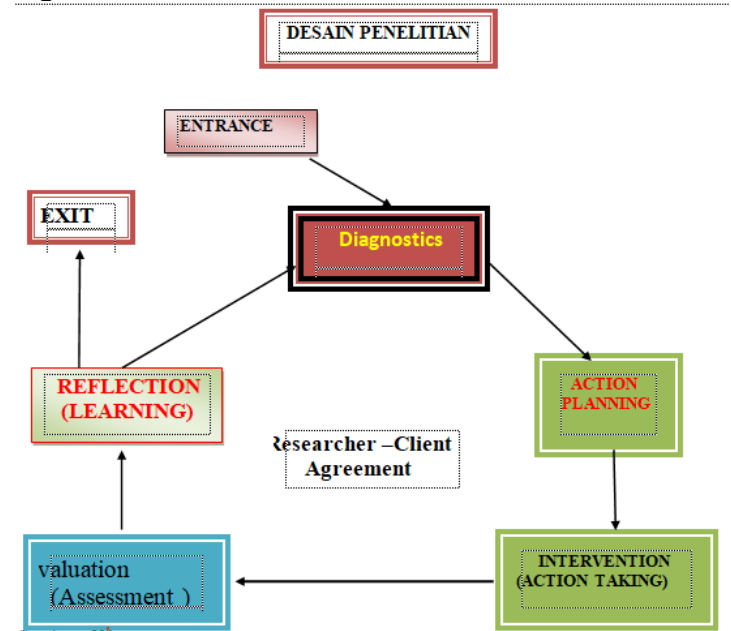

Figure 1 Research Design (Source: Modification: Sustainable, 2016)

Design Description:

Diagnostics: Low Role of Metacognition (Finding Out the Causing Factors)

Action Planing: To overcome the cause, the researchers planned the Implementation of ICT- Based Complex Problem-Solving learning methods ( SPSS Software ) to create and compile student learning modules for material statistics and develop modules with metacognition questions aimed at increasing the role of student metacognition and will later influence student statistical abilities.

Intervention (Action Taking): Application of Process of Complex Problem Solving by using ICT, namely SPSS software in class.

Evaluation: Provide tests (complex and realistic problems of students directed the analysis of multiple linear regression data of 4 variables). Observe during learning and give questionnaires to students' responses to the learning methods applied and observation of student activities.

Reflection: Overall evaluation results both test results, observation and questionnaires that students 'Metacognition is very influential and the results of students' statistical ability tests also increase then the 
research cycle is considered complete (EXIT) if the role of metacognition has not been optimal or increased and the student's statistical ability results have not increased then the cycle repeated until getting the desired results. Exit: Exit the research cycle if the application is according to the proper rules. In detail the research chart is presented below:

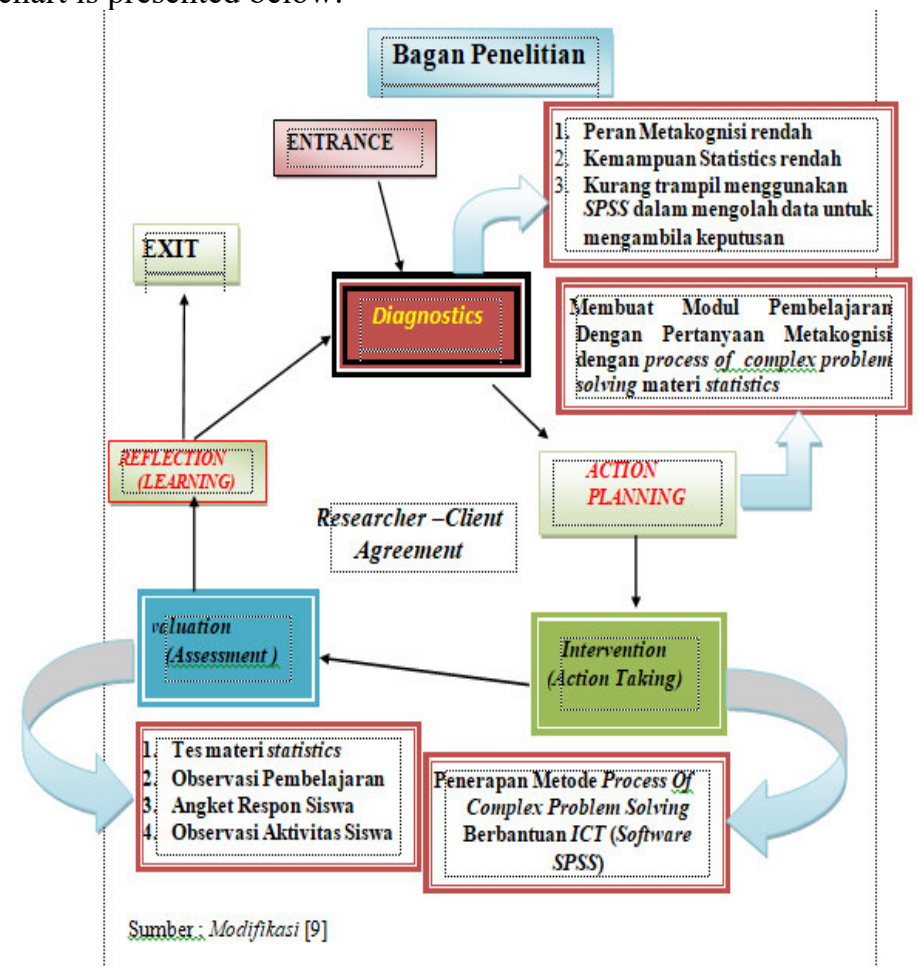

Picture. 2 Research Concept Maps.

\section{Results and Discussion}

The problem presented to stimulate the role of students' metacognition of their statistics ability is "Description of the problem about the volume of Seafood sales in the Bagan Percut area by following per under with the local culture so that it can more quickly stimulate the thinking power of students ( Ramadhani et al (2018) presented below

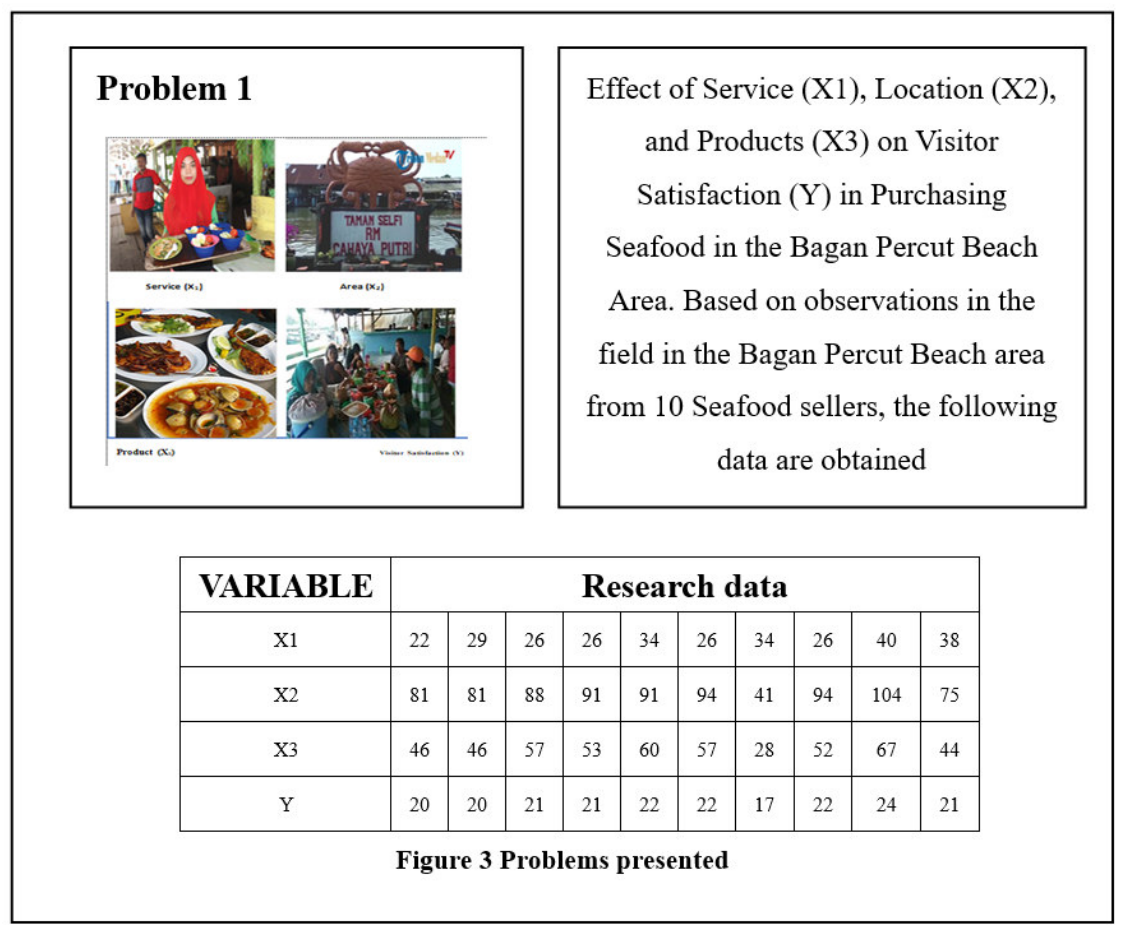

a. Determine the multiple regression equation $\mathrm{Y}$ for $\mathrm{X}_{1}, \mathrm{X}_{2}$, and $\mathrm{X}_{3}$ 
b. Analysis of the number of squares and degrees of variance free sources.

c. Test the significance of the multiple regression coefficient $\mathrm{Y}$ over $\mathrm{X}_{1}, \mathrm{X}_{2}$ and $\mathrm{X}_{3}$

d. Test the significance of the multiple correlation coefficient $Y$ over $X_{1}, X_{2}$ and $X_{3}$

e. T test for the significance of the coefficient of multiple regression equations.

f. Partial correlation and partial correlation significance test.

The metacognition questions posed on the evaluation instruments to stimulate students to stimulate their metacognition power are as follows,

* When you develop a problem-solving plan, ask yourself:

a. What initial knowledge will help you solve the problems above?

b. What did you first do after reading the questions?

c. How long will you complete this problem in full? why is that?

* When you are carrying out problem-solving, ask yourself:

a. What do you need to do if after reading the problem, but don't understand the problem given?

b. How do you solve the problem above?

c. Why are you sure that the answer process you made is correct?

After you have solved the problem, ask yourself:

a. Why did you use this method in solving the problem above?

b. How do you check the correctness of your answers above?

c. What did you learn after solving the problem above?

Furthermore, during the learning observed concerning things about the process of Complex problem solving (problem complex): 1. The solution handling the complex include: a) the acquisition of knowledge and b) application of knowledge about goal-oriented control system that contains many elements interrelated. Stages need to be done, namely: 1) Information media and technology: a) media literacy, ( Manitoba, 2008) b) visual literacy, c) multicultural literacy, d) Global Awareness, and e) Technolgy Literacy), 2 ) Life and Career Skills, 3) Learning and Innovative Skills, and 4) Effective Communication Skills. 2. Curiosity (curiosity) , 3. Creativity (creative), 4. Risk-Taking

Based on the above design in point 2 after a diagnosis of the student population at the Potential Main University, it was concluded that the factors causing some of them were developing ICT -based Statistics learning modules and the Process Complex Problem-Solving process by seeing the role of metacognition as a good solution. Furthermore, the module is developed and before it is applied to learning at the Potential Main University, instrument validation is performed to see the readability of the learning instrument. The results of the learning instrument validation are as follows,

\section{Normality of Research Data:}

Based on the trial results of the module readability and assessment instrument, the data obtained from the trial results and the normality of the data is calculated. The results of normality of data both metacognition abilities and statistical abilities are as follows,

Table 1 Normality of Readability Test

\begin{tabular}{|l|l|r|r|r|r|r|r|}
\hline & \multirow{2}{*}{ JK } & \multicolumn{2}{|c|}{ Kolmogorov-Smirnov } & \multicolumn{3}{c|}{ Shapiro-Wilk } \\
\cline { 2 - 8 } & Statistic & df & \multicolumn{1}{c|}{ Sig. } & Statistic & df & \multicolumn{1}{c|}{ Sig. } \\
\hline \multirow{2}{*}{ Metakognisi } & Laki-laki & .145 & 14 & $.200^{*}$ & .958 & 14 & .694 \\
\cline { 2 - 8 } & Wanita & .182 & 18 & .119 & .957 & 18 & .547 \\
\hline \multirow{2}{*}{ Statistik } & Laki-laki & .181 & 14 & $.200^{*}$ & .962 & 14 & .749 \\
\cline { 2 - 8 } & Wanita & .186 & 18 & .100 & .926 & 18 & .162 \\
\hline
\end{tabular}

Based on the data in table 1 above, it can be seen that the data content metacognitive ability for the Kolmogorov-Smirnov test is normally distributed at $0.102(>0.05)$ and for the statistical ability data on the Kolmogorov-Smirnov test with a normal distribution of $0.062(>0,05)$,. Furthermore, for the homogeneity test data on the two readability test data are presented in Table 2 below,

Table 2 Homogeneity Test Data Readability Test

\begin{tabular}{|c|c|c|c|c|c|}
\hline & Levene Statistic & df1 & $\mathrm{df} 2$ & Sig. \\
\hline \multirow[t]{4}{*}{ Metakognisi } & Based on Mean & .381 & 1 & 30 & .542 \\
\hline & Based on Median & .320 & 1 & 30 & .576 \\
\hline & Based on Median and with adjusted df & .320 & 1 & 28.024 & .576 \\
\hline & Based on trimmed mean & .377 & 1 & 30 & .544 \\
\hline \multirow[t]{2}{*}{ Statistik } & Based on Mean & .852 & 1 & 30 & .363 \\
\hline & Based on Median & .480 & 1 & 30 & .494 \\
\hline
\end{tabular}


Based on the data in Table 2 above, it can be concluded that the metacognition capability data is 0.395 , and the statistical ability data is 0.182 , where the results are $>0.05$, which means that both data are derived from homogeneous data. Therefore, these data qualify both linear regression that is both normal and homogeneous distribution of data then the next test linear regression $r$ to see whether the role of metacognition and the ability to statistically have a linear relationship according to the researcher's conjecture. Based on the results of processing the linear regression test data with SPSS 25, the linear regression test results are presented as follows,

Table 3: Linear Regression Test

\begin{tabular}{|c|c|c|c|c|c|}
\hline \multirow[b]{2}{*}{ Model } & \multicolumn{2}{|c|}{ Unstandardized Coefficients } & \multirow{2}{*}{$\frac{\text { Standardized Coefficients }}{\text { Beta }}$} & \multirow[b]{2}{*}{$\mathrm{t}$} & \multirow[b]{2}{*}{ Sig. } \\
\hline & $\mathrm{B}$ & Std. Error & & & \\
\hline \begin{tabular}{l|l}
1 & (Constant) \\
\end{tabular} & 57.178 & 7.377 & & 7.751 & .000 \\
\hline Metakognisi & .451 & 109 & .601 & 4.118 & .000 \\
\hline
\end{tabular}

Based on data processing, it can be seen that a constant value of 57,178 , slope value of 0,451 with a sig value of 0,000 , so that the regression equation is. $Y=57,178+0,451 X$. Furthermore, based on the results of data processing for the regression significance test with SPSS are as follows,

Table 4 Test the Significance of Regression

\begin{tabular}{|l|l|r|r|r|r|r|}
\hline \multicolumn{2}{|l|}{ Model } & Sum of Squares & df & Mean Square & F & Sig. \\
\hline \multirow{3}{*}{1} & Regression & 593.727 & 1 & 593.727 & 16.959 & $.000^{\mathrm{b}}$ \\
\cline { 2 - 7 } & Residual & 1050.273 & 30 & 35.009 & & \\
\cline { 2 - 7 } & Total & 1644.000 & 31 & & & \\
\hline
\end{tabular}

Based on the data in Table 4, it can be concluded that the regression test is significant because the sig value of $0.00(<0.05)$ and the $\mathrm{F}$ value of 16.959 so that it can be concluded that the regression equation coefficient is significant. Furthermore, for the regression line linearity test, it was obtained that the linearity deviation obtained by $\mathrm{F}$ was 0.787 with sig.0.651 greater than 0.05 , while for the Pearson Metacognition (X) and Statistical (Y) correlation with Statistic $(Y)$ of 0.601 with sig of $0.00(<0.05)$ so that it can be concluded based on the data above that the regression equation has a significant regression coefficient and linear regression lines and the Pearson Metacognition correlation $(\mathrm{X})$ with $(\mathrm{Y})$ is a significant correlation. In other words that the role of metacognition is directly proportional to the statistical abilities of students, so that if the role of metacognition is optimized it will affect student statistical abilities better, which means the learning process is optimized with ICT-based and the Complex Problem-solving Process which will have the role of student metacognition in learning statistics so that students' statistical abilities will increase in line with research ( Tayeb \& Putri 2017). character the students is needed in the era of industrial 4.0 are again faced by particular students of the University Main Potential and Indonesian students in general. This is also in line with research (Dianti, 2020, Funke, Fischer, Grefft. 2011, Nursamsu \& Kusnafizal. 2017, Muslih. 2016, Zulfachri, 2020) that ICT-based learning (GeoGebra\& Macro Media Flash) and the process of complex problem solving will improve mathematical problem-solving abilities and motivate students. In line with Rusmini's research (2018), Rusmini \& Surya (2019), Rusmini et al (2019) ICT-based learning has a significant effect on students' mathematical problem-solving abilities.

Based on the results up try legibility do in North Sumatra Muhammadiyah University in March 2019 the validity of the instrument in the category of valid and test readability assessment tool in getting a significant result that with the role of metacognition that both proportional to the statistical capacity of students, it is based data that has been processed by the $\mathrm{F}$ test is the calculated $\mathrm{F}$ value $>\mathrm{F}$ table. $\mathrm{y}$ and means instrument ratings also have the results of the linear regression equation and regression lines have Pearson correlation metacognition (X) and Statistics (Y) significant means and instruments of assessment modules can be used in field trials at the University Main Potential. Furthermore, students' responses to learning are positive responses based on a questionnaire distributed to students and based on observations at the time of learning that in general learning activities stimulate active students and learning seems to be more meaningful.

Furthermore, based on the evaluation made after learning it was found that the time needed in the learning much more effective where problems that do look at the role of metacognition in learning and based troubleshooting with a complex process that is with all the efforts that could be made to resolving problems both using ICT and the things that can support it maximally produce a very satisfying result. This we see from the results that have been made by students. They also felt very satisfied and commented that mathematics especially in solving statistical problems is a way that makes them less stressful and very pleasant. This means that a good perception arises from statistical learning after ICT-based learning and the Problem Solving Complex Process is similar to research ( Waru. VM, Mingger. I, Annas. S. 2015) 
Feelings of pleasure and conducive situations and meaningful learning will be a motivation in students in improving students' statistical abilities. And indirectly triggers the role of good metacognition. With a good metacognition role, students get used to always design and coordinate things that will be done so that the habit of doing things systematically and stimulating the metacognitive role of content in doing something is a skill or ability which is one of the strategies needed to face or live life in an era Industry 4.0 ( Satya, VE, 2018) Solving problems with a complex process will get maximum results or familiarize with the problems of Higher Order Thinking Skills (Helmmawati, 2019) creating reliable young generation.

\section{Conclusion}

Based on the trial results of legibility has been described above, it can The fish that learning expands the role of metacognition-based ICT and the complex process of problem-solving on the ability of statistics of students there is a very significant result for the role of meth a cognition is proportional to the statistical capacity of students and the response students are very good and are positive responses, student work results are fast and the learning process is more effective. But some things are positive factors and negative factors during learning. The details are as follows,

The supervisor must first make sure that every student has installed the SPSS in their laptop and they are already skilled in using the computer. Before learning mentor must first share the modules that have been developed and distributed to students as to them on completion of the issue so that when given their evaluations are used to make or use SPSS software because they can repeat at home independently.

Thank You To:

1. Kemenristekdikti-DRPM on the PDP grant scheme in 2020 funding

2. Potensi Utama University that has provided the opportunity and motivation to conduct research as well as a place to collect research data

3. Potensi Utama University students who also participated in the data collection through online learning using SPSS

4. Muhammadiyah North Sumatera University students who also participated in the instrtument validity.

\section{References}

Dianti N, Amry.Z, Siagian.P. (2020). Development of Learning Materials Through RME Assisted by Geogebra Software to Improve Students Problem Solving ability. Journal of Education and Practice www.iiste.org. ISSN 2222-288X (Online) Vol.11, No.8, 2020

Funke, Fischer, Grefft. (2011). The Process Of Complex Problem Soving. The Journal Problem Solving, Volume 4. No. 1 (Fall, 2011)

Helmawati. (2019). Pembelajaran dan Pneilaian Berbasis HOTS (Higher Order Thinking Skills). Bandung: PT Reosdakarya.

Lestari E.K, Yudhanegara (2015) Penelitian Pendidikan Matematika. Bandung : Refika Aditama

Manitoba. (2008). Literacy with ICT is For Me !. A Parent Handbook on Learning with Information and Communication Technology. Manitoba Education, Citizenship and Youth Cataloguing In Publication Data. Website at www.edu.gov.mb.co/k12/tech/lict/index.html.

Muslih. (2016). Pemanfaatan Media Pembelajaran Berbasis ICT pada Lembaga Pendidikan Non-Formal TPQ. Jurnal DIMAS Universitas Islam Negeri Walisongo Semarang. Volume. 16, Nomor 2, 2016.

Nugraha.D (2018). Workshop Technopreneursip“ Road to TBIC 2019” 30 September 2018. Dadannugraha74@gmail.com

Nursamsu \& Kusnafizal. (2017). Pemanfaatan Media Pembelajaran ICT Sebagai Kegiatan Pembelajaran Siswa Di SMP Negeri Aceh Tamiang. Jurnal IPA Dan Pembelajaran IPA (JIPA), 1(2): 165-170, Desember 2017. P-ISSN:2614-0500. www.jurnal . unsyah.ac.id/jipi

Riadi, E. (2016). Statistika Penelitian (Analisis Manual dan IBM SPSS).Yogyakarta:Andi Offset.

Ramadhani dkk (2018). The Development of Student Worksheet and Test Instrument for Statistical Thinking Skill Based On Local Culture and Accordance With Curiculum 2013 in Indonesia: Design Reseach Stage. Advances in Social Science Education and Humanities Research (ASSEHR), Volume 208. 1st International Conference on Social Sciences and Interdisciplinary Studies (ICSS)

Rusmini \& Surya E.(2019). Development of Oriented Student Activity Sheets Problem-Based Learning Approaches Assisted by GeoGebra Software to Improve Metacognition Ability of Private Vocational High School PAB 12 Saentis.Journal Education \& Practice Volume 10. No.9, 2019. p.166-170

Rusmini dkk. (2019). Pengembangan Lembar Kerja Siswa Berbasis Problem Solving Berbantuan Geogebra Untuk Meningkatkan Kemampuan Komunikasi Matematis. .Jurnal JPPM VOL. 12 NO. 2 (2019)

Satya, V.E. (2018). Strategi Indonesia Menghadapai Industri 4.0. Info Singkat Kajian Singkat Terhadap Isu Aktual Dan Strategis . Vol.X, No.09/I/Puslit/Mei 2018.

Tayeb \& Putri (2017). Kemampuan Metakognisi Untuk Meningkatkan Ketrampilan Pemecahan Masalah 
Matematika Siswa Kelas VIII B MTS Madani Alauddin Paopao Kabupaten Gowa. Jurnal Matematika Dan Pembelajaran (MaPan) Vol. 5 No. 1, Juni 2017

WMLN. (2019). World's Most Literate Nations. CCSU Connected State University @ 2019.

Waru. V.M, Mingger. I, Annas. S. (2015). Deskripsi Persepsi Tentang Statistik (Statistical Thinking) Pada Mahasiswa Jurusan Pendidikan IPS Terpadu Fakultas Ilmu Soasial Universitas Negeri Makassar. Jurnal Daya Matematis, Volume 3 Nomor 1 Maret 2015..

Zulfachri .F.R, Dewi. I, Molliq. Y. (2020). Development of Learning Tools Oriented Problem Based Learning Models Assisted by Macromedia Flash to Improve Mathematics Literacy Ability of Class X High School Students. Journal of Education and Practice .www.iiste.org ISSN 2222-1735 (Paper) ISSN 2222-288X (Online) Vol.11, No.15, 2020 